\title{
Changes in the retail sector in Budapest, 1989-2017
}

Tamás Sikos T. The retail network of in the Hungarian capital

University of Miskolc has gone through a significant change in the Institute of Management Sciences, last 30 years. This fundamental change can be

Hungary explained partly by global processes and is, to

E-mail: some extent, the result of the unique Hungari-

sikos.t.tamas@uni-miskolc.hu

National University of

Public Service

Faculty of Political Sciences and

Public Administration,

Hungary

E-mail: sikos.t.tamas@uni-nke.hu

an or Central European situation - that is, conditions of the Socialist era that were affected by contemporary European tendencies, but the system still had its own peculiarities and of the regime change. The changes in the last four decades have significantly altered the retail sector in Budapest and the shopping habits of its inhabitants. Quality of life has also fundamentally changed, as have living standards. In addition to the spread of mobilisation, new satellite technologies have brought

Keywords: considerable changes in the field of trade as retail trade of Budapest, well. Today, the question is not how close we shopping centres, are to the developed world but how fast we consumer behaviour, can gain access to suitable services and basic geomarketing, supplies and how these supply chains are ortypology of shopping centres, ganised. In our globalised world, a new form urban structure, of harmony must be created between globality CBD and locality.

\section{Introduction}

Although this paper describes the changes in the retail network of Budapest, some of the findings are also relevant at the national level. Shopping centres are still the 'new cathedrals' of consumption - even given their sizes - and have a stronger impact on the city's spatial structure than previous department stores did. (In 2017, the total floor area of shopping centres in Budapest exceeded 1.2 million $\mathrm{m}^{2}$ ). Today, shopping centres do not only formulate the spatial structure of commercial zones but in many cases endanger the existence of department stores and small shops. The emerging conglomerates affect not only the structure of shop chains but also the constantly changing spatial structure of the city and consumer behaviour (Sikos T.-Hoffmann 2004a, 2012).

Thus, this study addresses not merely the structural changes in the Hungarian capital but also shopping centre locations and their typologies. In our previous studies, similar analyses were done on Bratislava, Slovakia, Prague, the Czech Republic,

Regional Statistics, Vol. 9. No. 1. 2019: 135-149; DOI: 10.15196/RS090104 
and Vienna, Austria (Sikos T. 2012, 2013), followed by a detailed analysis of Vienna and Bratislava (Mitrikova et al. 2016, Kita-Grossmanová 2014, Krizan. et al. 2018). Our studies are based on relevant theoretical and methodological foundations. Our previous typology of shopping centres, similar to this study, is based on the model developed by Dawson (1983) (Dawson-Mukoyama 2013). The strategies and trends used to select the locations that we describe in this study are also in accordance with the works of Brown (1991) and Borchert $(1994,1998)$. The theoretical and methodological research on the subject examined is outstandingly relevant in light of the change in the regime because economic processes in a planned economy operate differently from those under free market conditions. At the same time, satisfying consumer needs at the highest possible level in both quality and quantity became a priority. In my research, I concentrated not only on the processes and shopping centres at the top of the pyramid but also attempted to follow how traditional retail trade lost space (Sikos T. 2000, 2004). This study provides a good opportunity for a detailed review of retail processes.

\section{Methodology}

The method used in this research was based on processing significant quantities of data collected from a large number of questionnaires. Here, we emphasise that all of the volunteers participating in the survey were selected randomly; however, despite this fact, the sample cannot be considered representative. Data were processed using the mathematical and statistical software package SPSS 20. In addition to traditional fieldwork methods, GIS technology (Tóth-Csomós 2016) and digital analysis methods offered by Google Earth were used to analyse changes in businesses.

\section{Structural characteristics of retail zones in Budapest}

The evolvement of the most important retail areas in the Hungarian capital is closely connected to the development history of Budapest. In the topographic development of Budapest, among the urban development and urban regulation measures, the most important one was probably the reshaping of the downtown area, which became necessary when the Erzsébet híd (Elizabeth bridge) was built. Construction was completed during World War I; however, the modern city centre of the metropolis was only completed after the war. During this period, the traditional shopping zone of the capital was developed in the Vörösmarty tér-Károly körút-Kossuth Lajos utca-Danube area. This zone is still one of the most elegant and reputable business zones in the capital and, simultaneously the most expensive shopping area. Regarding its function, the zone fulfils the same role as Kärtner Strasse, the shopping street of Vienna.

In reshaping the downtown area, banning traffic from the central business district and making the northern part of Váci utca a pedestrian street were significant

Regional Statistics, Vol. 9. No. 1. 2019: 135-149; DOI: 10.15196/RS090104 
steps. This process started at the end of the 1970s, but the construction of the pedestrian area in the southern section of Váci utca took place only in the second part of the 1990s. The retail characteristics of the northern and southern parts of Váci utca also differ: the northern part is home to trading luxury items, whereas the southern part can be characterised as traditional retail trade. Presently, the northern and southern parts of Váci utca are clearly separated. Szabadsajtó út and Kossuth Lajos utca cross the area, which increases the feeling of separation between the two halves of the street. In the long run, however, the luxury zone will probably spread to the south and, over time, a bipolar commercial core might evolve the downtown area (see Figure 1).

\section{Commercial zones of Budapest, 1996 and 2008}

Figure 1

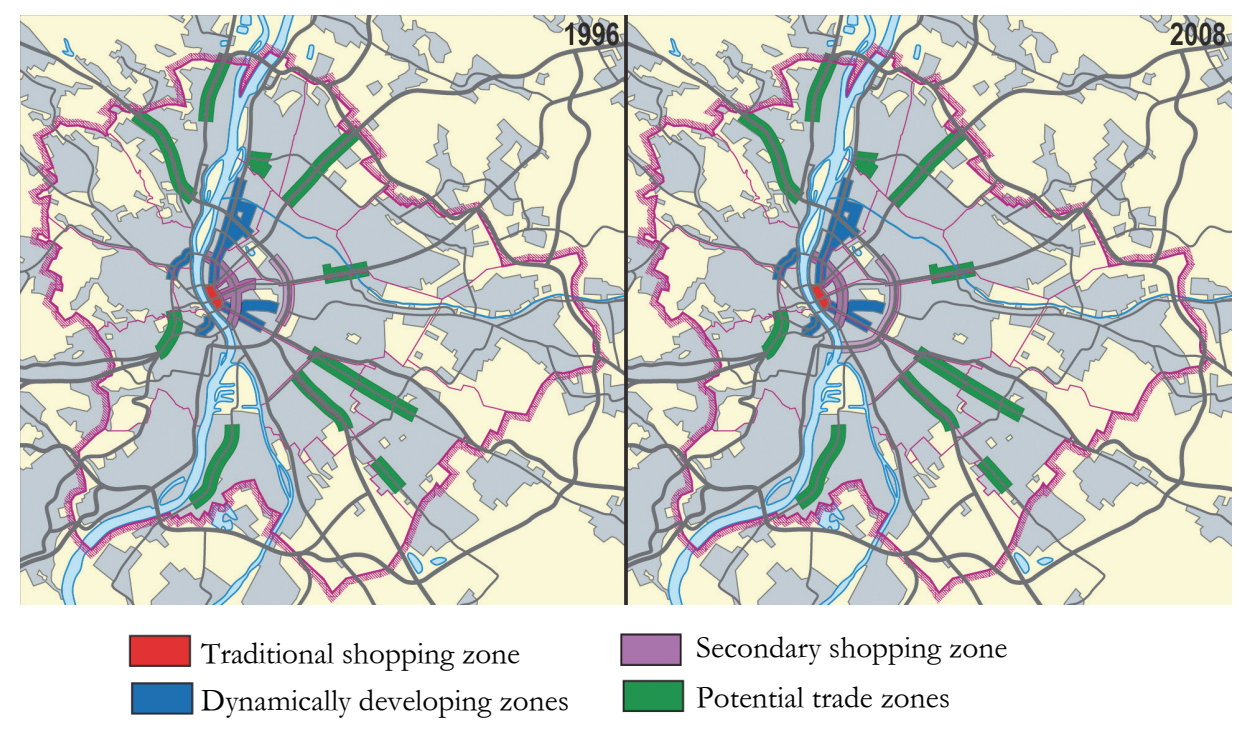

Source: Sikos T. (2009).

The commercial role of Rákóczi út became more articulated after the Erzsébet híd (Elizabeth bridge) was built but remained secondary relative to the northern part of Váci utca until 1996. The larger department stores of Rákóczi út (Corvin, Verseny, Csillag, and others) were closed down (2008), the range of goods they sold used to belong to the low-end market anyway, and items sold in Váci utca and its neighbourhood were high quality, up-market products.

Nagykörút - located between Margit híd and Petőfi híd - is an organic part of the secondary shopping zone. This area is mainly characterised by small shops that had, in many cases, not more than $20-50 \mathrm{~m}^{2}$ of floor size, sometimes even smaller. In Nagykörút, the total size of the shop floor is approximately $150,000 \mathrm{~m}^{2}$. Recently, retail trade in Váci út has been dynamically developing and shops with large floor

Regional Statistics, Vol. 9. No. 1. 2019: 135-149; DOI: 10.15196/RS090104 
area that had to leave their previous locations because of high rental fees resettled here from the downtown area and the secondary shopping zone.

Next to roads leading out of the city, another commercial zone appeared in which mainly car trader companies, used car parts yards, solid fuel merchants, and building material and supplies yards, requiring large spaces, settled down. An analysis of the structure of Budapest's commercial zones indicates that the development trend is similar to that of large south European cities decades ago (see Figure 1).

In Budapest, shopping malls were first built in the 1970s (Flórián, Skála), ${ }^{1}$ but their spectacular and explosive development started only in the 1990s. The 80 smaller retail units that we view as units belonging to a shopping centre (2008) have a significant impact on Budapest's spatial structure and its formulation (see Figure 2).

Figure 2

\section{Types of shopping centres in Budapest, 2008}

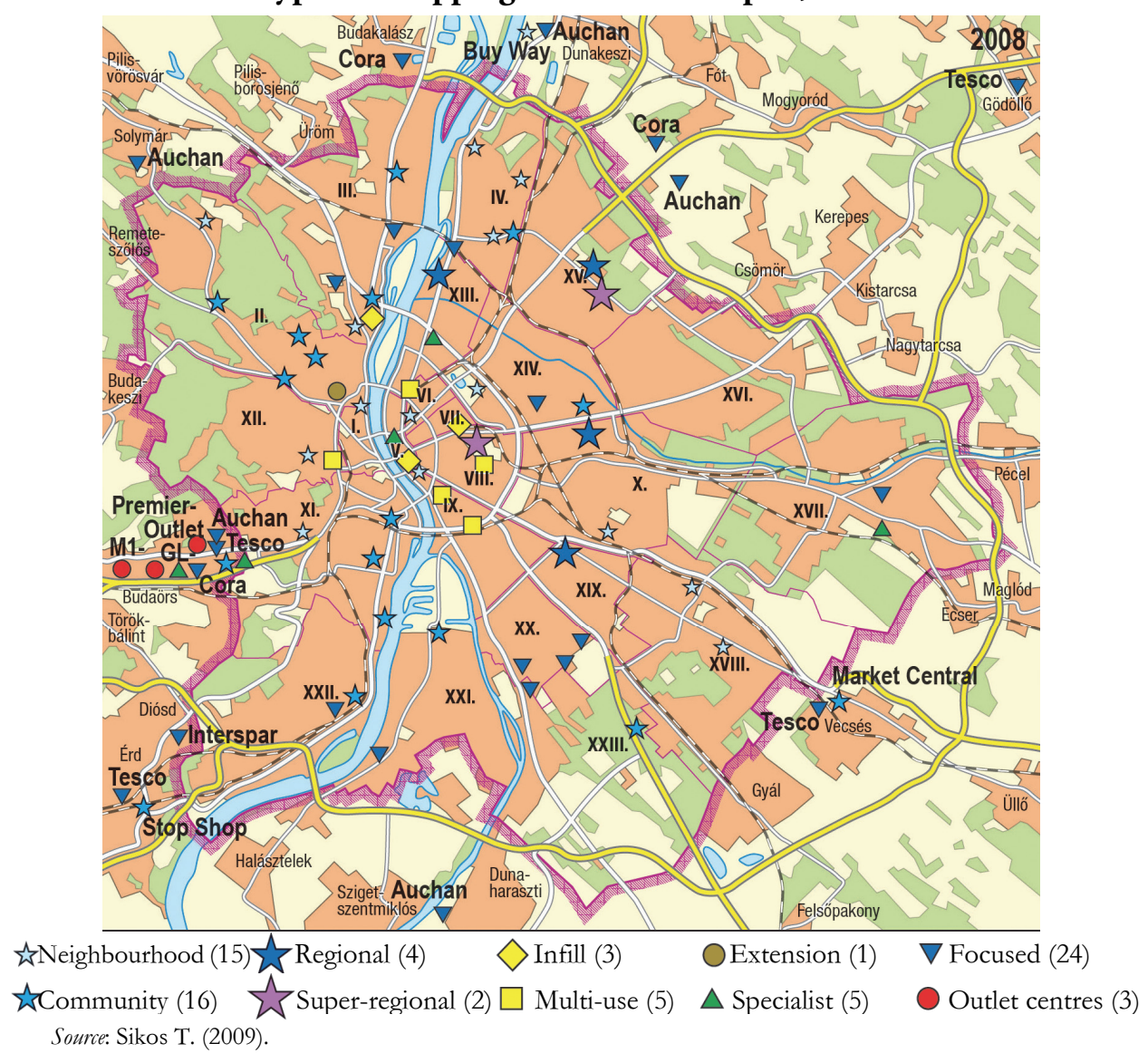

${ }^{1}$ At the location of the former Skála department store (opened in 1976), the Allee shopping centre has been operating since 1996.

Regional Statistics, Vol. 9. No. 1. 2019: 135-149; DOI: 10.15196/RS090104 
In the capital, 16 shopping centres play a regional role, and the number of hypermarkets in Budapest and its agglomeration is 25. The development of the transport network in the capital could hardly keep pace with the rapid appearance of new retail units, and the hindering effect of this situation can still be sensed in some shopping centres. Until 2008, during the economic downturn, the structure of retail trade in Budapest and its agglomeration zone was developing dynamically but then came to a halt. A significant portion of the Hungarian population took out Swiss franc-denominated loans and became indebted, ${ }^{2}$ causing purchasing power in commercial centres to decline, which negatively affected further investments. During the crisis, households started to elaborate on special strategies and ways to minimise their losses.

\section{Effect of the crisis on retail trade}

Because of the global economic crisis, the dynamism of retail trade declined (Kocziszky et. al. 2018). There was a significant break in the expansion of retail trade complexes. In this situation, even ongoing investments halted (see the Tó-park project), and new ones were not launched in the market after 2011. Among projects in progress before the crisis, the second phase of Allee (2009), Corvin Plaza (2010), Europeum (2011), Hegyvidék Bevásárlóközpont (2012), and Árkád (2013) was completed.

After 2008, the retail network in the capital was mainly expanded with 20 hypermarkets built as of 2017. However, after the completion of the second phase of Árkád (2013), no new shopping centre was built in the capital. Presently, a few new projects are being prepared, but they will not be implemented until the economic situation stabilises. The preparation process for building a shopping centre generally takes four or five years. For the Árkád shopping centre, the process took five years.

Retail trade was further burdened in this challenging economic period. First, companies with a retail profile were progressively taxed (2011), and, second, the 'Plaza stop' law (a ban on building shopping centres) ${ }^{3}$ came into effect (2011), which stipulated that permission is needed to establish retail units.

\footnotetext{
${ }^{2}$ Many real estate and car buyers became indebted given changes in the exchange rate of the Swiss franc.

${ }^{3}$ The amendment bans building retail outlets larger than $300 \mathrm{~m}^{2}$ (shops and shopping centres) and calls for expanding existing outlets to larger than $300 \mathrm{~m}^{2}$ until the end of 2014 in Hungary. Therefore, until then, no shopping centres, supermarkets, hypermarkets, or discount stores were to be built. However, the amendment left a loophole: the minister of trade - based on the opinion of the committee, including the ministers of trade, environmental protection, and rural development - is authorized to make exceptions to the law. (http://koos.hu/2011/12/13/plazastop-300-m2/)
}

Regional Statistics, Vol. 9. No. 1. 2019: 135-149; DOI: 10.15196/RS090104 
Types of shopping centres in Budapest, 2017

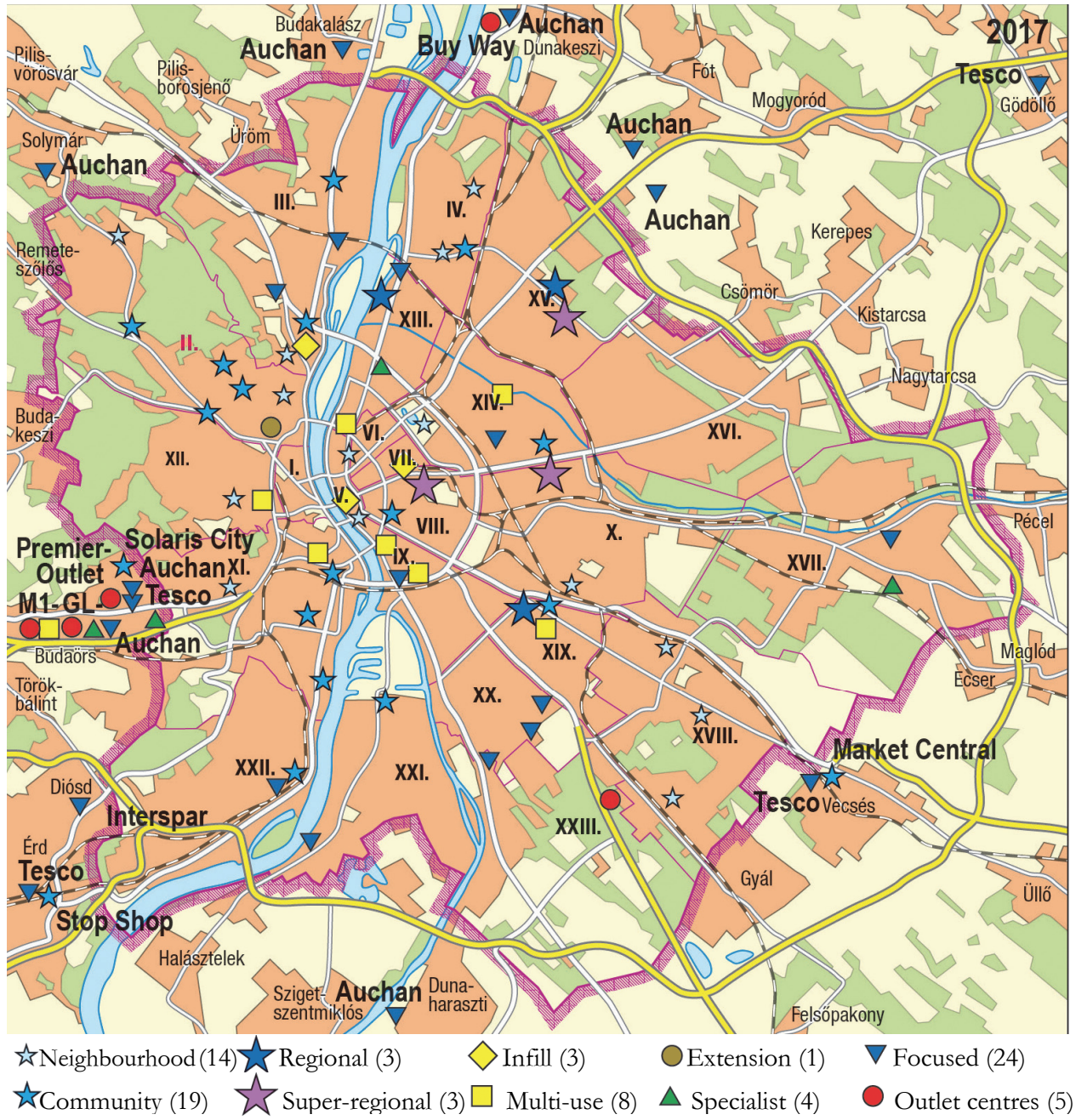

Regional Statistics, Vol. 9. No. 1. 2019: 135-149; DOI: 10.15196/RS090104 
The 'Plaza stop law 2' that came into force that year ${ }^{4}$ was extended, and it regulated the proposed changes to shopping centres. The re-division and regulation of the national tobacco market was also a sensitive issue for the operation of commercial centres.

Under these conditions, a government measure was born that banned retail units from opening on Sundays. This central regulation came into force on 15 March, 2015. Relative to previous periods, the new commercial law considerably limited the Sunday and night opening hours of retail outlets with more than $200 \mathrm{~m}^{2}$ of floor space. Act CII of 2014, 'on prohibition of work on Sundays in the retail sector', prohibits retail units from opening between 10:00 p.m. and 6:00 a.m. on business days and Sundays, except for small retail stores operated by the owner. The decree aimed to enhance the competitive position of small shops and businesses.

This measure contradicted the liberal practices of the previous decades, strongly influenced the shopping habits of the population accustomed to continuous opening hours, and had a negative effect on people's feelings of comfort. Therefore, the measure had significant publicity among both its supporters and opponents. In addition to the social impacts that could be almost immediately sensed, the act indicated a significant rearrangement in the retail sector by changing buyers' time dimension.

Our research also highlights this point. Data collection was carried out in two phases: before the introduction in January and February 2015 of the Sunday closure and after the act came into force in April and May. The sample size $(N)$ was 151 in phase one and 121 in the second phase of the research. Respondents were selected by using a simple random sampling method (Kovács-Sikos T. 2015). The sample consisted of respondents living in the capital, large cities, small towns, and villages. However, choosing a territorially representative sample was not possible because of the sample size.

The compulsory Sunday closing affected mainly shopping centres. These retail stores with large floor sizes can be regarded as a sort of new 'city centre' and new 'cathedrals of consumption' offering not only commercial but - in a broader sense service, cultural, and community functions as well. More than one-quarter of the people asked in our survey visited one of the shopping centres on Sundays. This group of potential buyers disappeared from the shops after 15 March, 2015 (see Figure 4).

\footnotetext{
4 The legislator ordered that a specialized authority shall participate in the evaluation of tenders to build a shopping mall. The authority gave its resolution concerning environmental, traffic, and urban development effects on the proposed location and gravity zone of the planned investment. They participated in issuing building permissions for building or altering retail units larger than $400 \mathrm{~m}^{2}$ of gross floor space and for expanding existing units to this size - these activities required building permission. http://www.kormanyhivatal.hu/hu/zala/hirek/februartolhatalyos-a-plazastop-2
}

Regional Statistics, Vol. 9. No. 1. 2019: 135-149; DOI: 10.15196/RS090104 


\section{Time dimension of shopping before and after 15 March, 2015 in shopping centres and small shops}

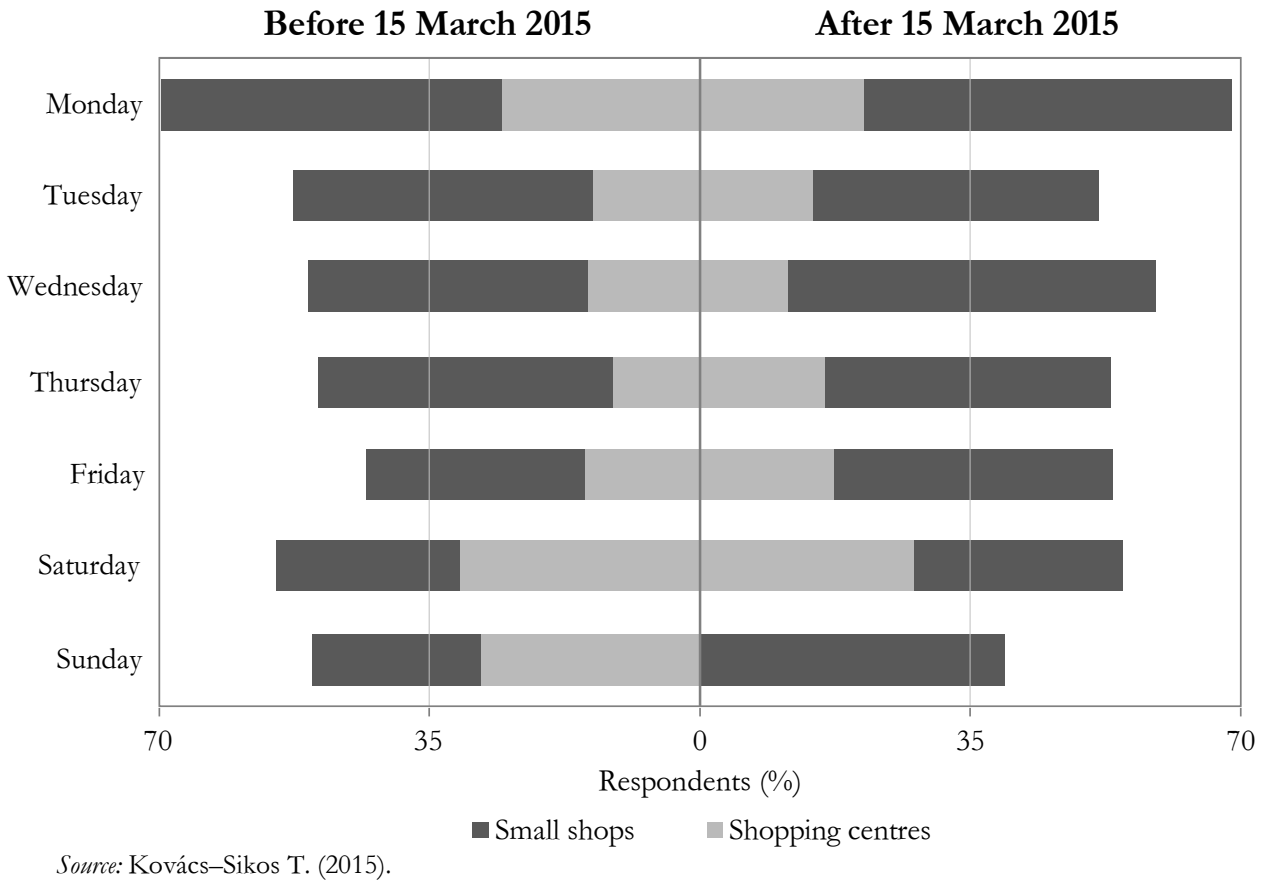

After the act came into force, Sunday shopping - even though to a smaller extent - was channelled to the other days of the week; however, at the same time, turnover in shopping centres in general declined. Businesses attempted to protect themselves against Act CII of 2014 in two ways: they extended the opening hours and reduced their prices. Given these processes, the impacts meant barriers for the companies - they generated uncertainty and unpredictability in business - and resulted in tightening instead of expansionary measures.

The significant insecurity (in business and in life) to which we referred earlier had its impact on individual lives and households as well. The changes can be detected in rationalised spending. The previously flourishing, successful commercial areas and zones were rearranged, and the losers and winners could be clearly separated in the shopping centre market. The real winners in the market were Duna Plaza, WestEnd City Center, Árkád, Aréna, Europark, and Mammut, for which the secret of their success was their thorough site selection policy.

Obviously, losers can explain their failures using the same reasons; moreover, a badly chosen location in an unfortunate business environment worsened their situation. Csepel Pláza, a member of the Plaza Center group, is an example of this situa- 
tion: here, the purchasing power potential of the area was incorrectly estimated. Investors opened Lurdy Ház in an area that lacked businesses, but the shopping centre is difficult to reach on public transport, and the purchasing power in the area is rather low. In the case of Új Udvar and Rózsadomb Center, the impact of incorrect site selection is worsened by the unsuitable building, unfortunate shop mix, and unattractive morphologic features.

Some shopping centres fell back from their former leading positions (e.g. Pólus Center) mainly because their role became secondary. The so-called domino principle is determinative, which indicates that new entrants continuously rewrite the rank of shopping centres in the market.

Campona is a good example of this phenomenon, with a market position that significantly improved by building a tropicarium. The shopping centre, also built in an area that had an undersupply of shops and stores, partly owes its favourable position to this undersupply and partly to the fact that it stands alone, away from its competitors and with its own, well-defined gravity zone. Opening the tropicarium resulted in a $20 \%$ increase in the number of visitors, and its previous $80 \%$ saturation index jumped to $100 \%$. Eleven Center was not as fortunate regarding its utilisation $(35 \%)$. These unfavourable numbers are the result of incorrect site selection. Although Gazdagréti lakótelep (housing estate) would mean enough purchasing power for the centre, investors failed to calculate the extraction effect of the shopping centres in the Budaörs-Biatorbágy-Törökbálint triangle.

Shopping centres in the western gate of the capital have a significant impact on the region, even though their shop network remarkably weakened after the crisis, and many stores in the area went bankrupt or were sold. It is very likely that, in the future, building of shopping centres will take a turn and hypermarkets will enjoy priority (see Figure 4). We will also have to count on a new, upcoming direction - the expansion of e-commerce - which will act increasingly as a supplement to shopping centres and hypermarkets.

\section{Customer opinions on shopping centres}

Hungarian buyers accepted, learned to like, and visited shopping centres in a relatively short period. However, acceptance does not equal a long-lasting positive attitude. For businesses, loyal and satisfied customers who return are a valuable asset that can be relied on in the long run. It was also important to examine what customers think about shopping centres when Act CII of 2014 - regulating the opening hours in the retail sector - came into force and when it was eventually withdrawn. ${ }^{5}$

${ }^{5}$ We must note that in a 2016 study of ours, when 472 people were surveyed on Facebook, two-thirds of them rejected the Sunday closure and voted for the stores to re-open (Sikos T.-Kovács 2017).

Regional Statistics, Vol. 9. No. 1. 2019: 135-149; DOI: 10.15196/RS090104 
Research was carried out using 163 respondents in Budapest shopping centres who were selected through a simple random sampling method. We aim to indicate that the emotion-driven opinions of customers can be favourable if they are positive or disadvantageous if they are negative.

The opinions of the surveyed individuals on shopping centres was more positive than negative, and $54.6 \%$ of them stated that people either like very much or like these establishments, $42.9 \%$ both like and dislike them, and only $0.6 \%$ claimed to dislike them. According to this response, on a scale of 1 to 5 , the attitude index is 3.62, indicating that the 'like' rating was predominant. Obviously, this score does not indicate loyalty, support, or returning because we discuss subjective feelings and generalisations. In these cases, people seemingly make abstractions because researchers ask for general opinions, but respondents always respond with what they think about the object, place, or concept in question. Shopping centres had positive ratings, and answers regarding the reasons also reflected these ratings (see Table 1).

Table 1

Attitude indices on Budapest shopping centres*, 2016

\begin{tabular}{l|c}
\hline \multicolumn{1}{c|}{ Statement } & Index value \\
\hline I can shop on weekends & 4.79 \\
Wide selection & 4.17 \\
Encourage wasteful expenses & 3.99 \\
Offer temptation & 3.68 \\
Increases prices of goods/services & 3.67 \\
Everything under one roof & 3.65 \\
Good experience & 3.64 \\
Planned & 3.54 \\
Comfortable & 3.43 \\
Negatively affects children & 3.30 \\
Small shops are more favourable & 2.87 \\
Helpful service & 2.75 \\
No crowd & 2.64
\end{tabular}

* To calculate the attitude index, we multiply the distribution ratios by the weights of $1-5$, add them up, and divide by 100 . The resulting value may range from 1 to 5 .

Attitude indices also underpin the previous findings that showed that weekend shopping possibilities (4.79) and wide selection (4.17) are the most determinative in accepting shopping centres; therefore, being open on Sundays is important to customers. We must also emphasise that customers do not condemn temptation (3.68) but consider it an acceptable feature of shopping centres. Similarly, putting everything under one roof is also considered a positive feature (3.65). At the same time,

Regional Statistics, Vol. 9. No. 1. 2019: 135-149; DOI: 10.15196/RS090104 
as another study revealed (Sikos T.-Hoffmann 2004b), service is regarded as poor (2.75), and the index hardly reaches the average.

Buyers find shopping centres crowded (2.64), which is not surprising because it is difficult to move around in most of them, especially in the early evenings and on the weekends. In vain, businesses attempt to help the situation because the width of the corridors, the size of the shops, and other passageways are set, even though they may differ for each shopping centre depending on the planned number of visitors and the expected intensity of shopping.

Adults are unsure when deciding on whether or not shopping centres negatively affect children. Because the relevant index (3.3) is comprised of 'both yes and no' answers, it is not negative. This is a good reason against the opponents of shopping centres, many of whom based their negative opinions on the negative impact that shopping centres have on children. Customers agree only partly with the statement that shopping centres encourage wasteful expenses (3.99) and offer temptation (3.68). The index for temptation could be higher from a marketing point of view, even if respondents partly agree with the statement (approximately a value of 4).

Also favourable is that the majority of the people surveyed stated that shopping centres do not incite waste, namely, make us buy products we do not need. People are not tempted by the large volume of products and can resist buying them, which enables them to avoid the uncomfortable feeling of cognitive dissonance.

\section{Reasons for choosing shopping centres, 2016}

Figure 5

\section{Do you agree with the following statements? (Budapest inhabitans)}

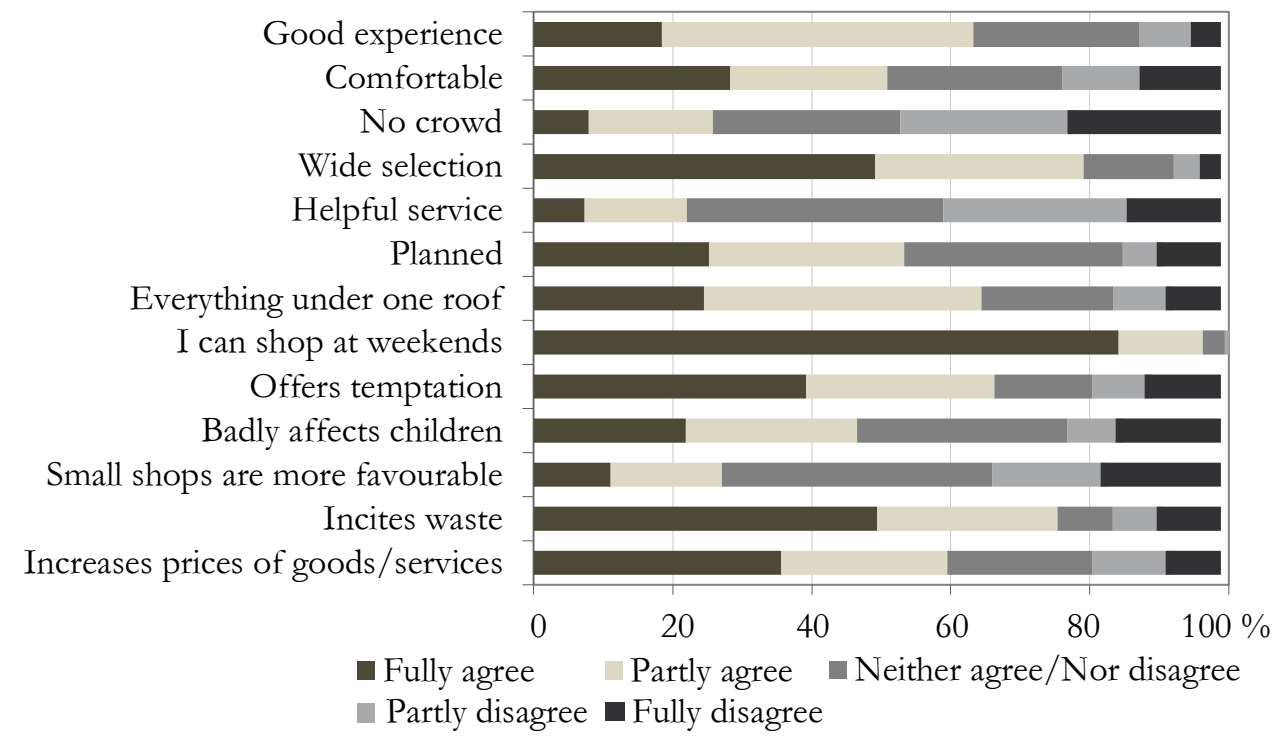

Regional Statistics, Vol. 9. No. 1. 2019: 135-149; DOI: 10.15196/RS090104 
We state that buyers leaving shopping centres are mostly satisfied, and feeling regret after buying something is rare. This feeling might also play a role in why Hungarian buyers grew to like retail units with large floor sizes (see Figure 5).

The survey indicated that the majority $(55 \%)$ of those surveyed have the opinion that prices in shopping centres are fairly high, and that quality is regarded as average by the overwhelming majority $(72 \%)$. This situation cannot be viewed as favourable because it reflects a shift in the price-quality ratio and that the probability that buyers will return decreases. In other words, according to customers, stores in shopping centres charge higher prices than they should considering the quality of the products, as indicated by the attitude indices (see Table 2).

Table 2

Opinion of customers on prices applied by shopping centres and the quality of goods, 2016

\begin{tabular}{l|c|c}
\hline \multicolumn{1}{c|}{ Buyer sample } & Price & Quality \\
\hline Total sample & 3.53 & 3.21 \\
Intellectual worker & 3.48 & 4.12 \\
Holding academic degree & 2.75 & 2.62 \\
Inhabitant of Budapest & 4.61 & 4.61 \\
21-30 age group & 2.75 & 4.61
\end{tabular}

Note: Maximum value $=5$.

The opinion of individuals holding academic degrees and the 21-30 age group is significantly different from the average. People living in the capital consider prices to be high, and youngsters judge them favourably. The same refers to quality. Among customers in shopping centres, we often find that young, white-collar workers - especially women - apparently consider prices close to the average and quality higher than the average. This finding is in contrast to the entire sample, which judges the quality to be the same as anywhere else. People with academic degrees view both prices and quality as average and only buy products in shopping centres in exceptional cases. In this segment, the negative attitude that characterises environmentally conscious social groups can be detected.

Because young, intellectual workers are overrepresented in the sample (43-44\%), the findings of this research apply to this segment. This situation is favourable for stores in shopping malls because the most frequent buyers view prices as reasonable and regard the quality as good. They also consider the operation of shopping centres as important.

The Hungarian government - in reaction to pressure from shopping centres and buyers - withdrew Act CII of 2014, a step that was received positively. Of the people asked on Facebook through the assistance of a Google online questionnaire, more than 65\% voted for Sunday openings and 35\% preferred Sunday closures (see 
Figure 6). Our analysis also justified that shopping habits had changed. The spread of e-commerce must be increasingly considered, whereas comfortable shopping is becoming a priority for consumers.

Figure 6

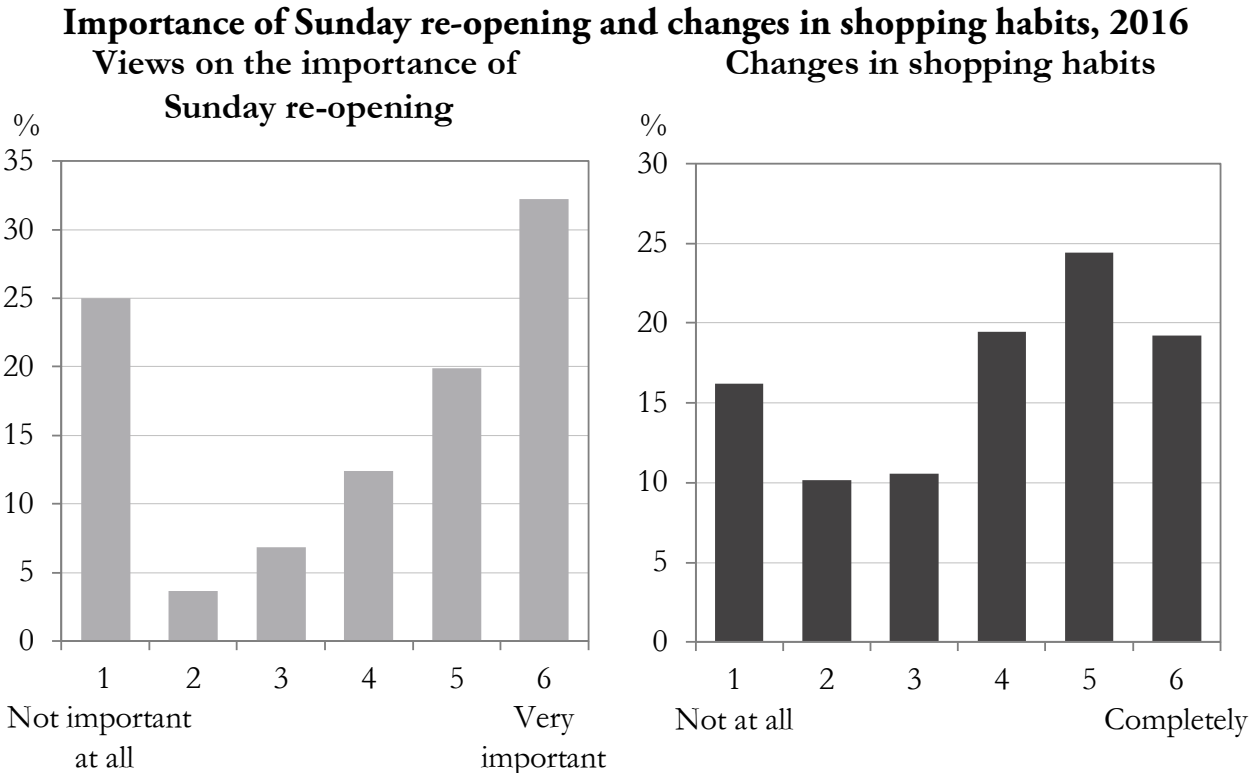

\section{Conclusion}

Based on the described and multilaterally evaluated results of our research, the following important conclusions can be drawn about the changes in Budapest's retail sector.

- In the last 40 years, the retail network in Budapest was built, and its further development and renewal depend on future market conditions.

- The global economic downturn set back the expansion of shopping centres in Budapest, and the last significant investment was completed in 2013 when the number of shopping malls was 101. Presently, two malls are under construction in the Hungarian capital (Etele Plaza and Óbudai Plaza).

- Shopping centres were received positively, and buyers remained committed to their re-opening on Sundays even when the government regulated opening hours in the retail sector through Act CII of 2014. The majority of Hungarian society (two-thirds of them) did not accept the Sunday closure because it significantly hindered their schedules and costs (travel costs, waiting, and crowds). 
- Between 2014 and 2016, consumer behaviour changed remarkably (in shop preferences and spending). The division in purchase costs also changed; in particular, the share of government-supported retail units - small shops - increased in the case of FMCG products, and the turnover of other market players did not considerably change.

- Regulating the opening hours also affected consumer habits. The changes resulted in an increase in e-commerce, a comfortable shopping alternative for buyers.

\section{REFERENCES}

Borchert, J. G. (1994): Urban marketing. A Review In: Braun, G. O.-Korn, H.Linemann, A.-Schultz, G.-Woosname, J.-Woosnam Managing Marketing of Urban Development and Urban Life. pp. 415-428., Deitrich Reimer, Berlin.

BORCHERT, J. G. (1998): Spatial dynamics of retail structure and the venerable retail hierarchy GeoJournal 45(4): 327-336. https://doi.org/10.1023/a:1006976407047

BROWN, S. (1991): Tenant placement in planned shopping centres: implications of an observation survey Journal of Property Research (8): 179-187. https://doi.org/10.1080/09599919108724032

DAwson, J. A (1983): Shopping Centre Development Longman, London.

Dawson, J. A.-Mukoyama, M. (2013): Global Strategies in Retailing: Asian and European Experiences. Routledge, London.

KitA, P.-GrossmanovÁ, M. (2014): Reflection of Bratislava Retail Network in Selected Aspects of Consumer Behaviour Verslas: Teorija ir Praktika/Business: Theory and Practice 15(3): 279-284. http://dx.doi.org/10.3846/btp.2014.28

KriZAN, F.-BILKOVA, K.-BARLIK, P.-KITA, P. (2018): Spatial distribution of consumer preferences: Case study of shopping malls in Bratislava Theoretical and Empirical Researches in Urban Management 13(1): 13-21.

KoCZISZKY, GY.-BENEDEK, J.-SZENDI, D. (2018): The impact of the 2008 financial crisis on household income and wealth in Visegrad countries Regional Statistics 8(1): 141-167. https://doi.org/10.15196/RS080102

KovÁCs, A.-SIKOS T., T. (2015): Effects of Sunday closure on Hungarian shopping behaviour EUGEO Budapest Congress programme and abstracts. Hungarian Geographical Society Budapest.

Mitrikova, J.-SenkovÁ, A.-Antolikova, S.-PArova, V. (2016): The analysis of shopping behaviour in the context of spending leisure time activities of consumers in the chosen shopping centres in Vienna (Austria) Economic Annals-XXI 161(9-10): 71-74. https://doi.org/10.21003/ea.V161-16

SIKOS T., T. (2004): Siker vagy kudarc? A barnaövezet hatása a budapesti bevásárlóközpontok fejlődésére In: BARTA, GY. (szerk.): A budapesti barnaövezet megíuluási esélyei pp. 181-191., MTA Társadalomkutató Központ, Budapest.

SIKOS T., T. (2013): Wien - die Transformation einer traditionsbewussten Stadt und das Erscheinen der Einkaufszentren Klagenfurter Geographische Schriften 29(1): 15-31. Paper 6.

Regional Statistics, Vol. 9. No. 1. 2019: 135-149; DOI: 10.15196/RS090104 
Sikos T., T.-KovÁcs, A. (2017): A vásárnapi zárvatartás megszűnése Magyarországon vásárlói vélemények és várakozások Földrajzi Közlemények 141(2): 139-151.

Sikos T., T.-Hoffmann, I.-NÉ (2004a): A fogyasztás új katedrálisai. Magyarország az ezredfordulón: stratégiai tanulmányok a Magyar Tudományos Akadémián, MTA Társadalomkutató Központ, Budapest.

SIKOS T., T.-HofFMANN, I.-NÉ (2004b): Budapesti bevásárlóközpontok tipológiája Földrajzi Értesitó 53(1-2): 111-127.

Sikos T., T. (2009): A marketingföldrajz kialakulásáról és feladatairól. Magyar Tudomány (6): 642- 650 .

SIKOS T., T. (2012): Budapesti bevásárlóközpontok Területi Statisætika 52(6): 583-591.

Sikos T., T.-HofFMAnN, I.-NÉ (2012): A kiskereskedelem új kihivói: Bevásárlóköapontok Budapesttól Prágáig Akadémiai Kiadó, Budapest.

SIKOS T., T. (2000): Marketingföldrajz VÁTI, Budapest.

TóTH, G.-CsOmós, GY. (2016): Mapping the position of cities in corporate research and development through a gravity model-based bidimensional regression analysis Regional Statistics 6(1): 217-220. https://doi.org/10.15196/RS06111

\section{INTERNET REFERENCES}

http://koos.hu/2011/12/13/plazastop-300-m2

http://www.kormanyhivatal.hu/hu/zala/hirek/februartol-hatalyos-a-plazastop-2

Regional Statistics, Vol. 9. No. 1. 2019: 135-149; DOI: 10.15196/RS090104 